
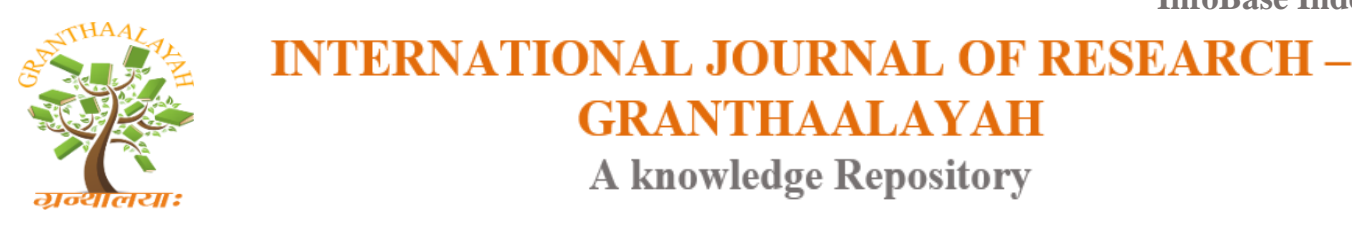

Social

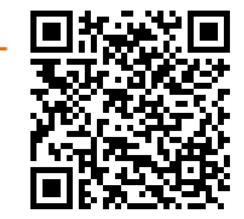

\title{
AN ANALYSIS OF THEORETICAL AND EMPIRICAL STIDIES ON METADISCOURSE
}

\author{
Lichan Wang', Yi Zhang ${ }^{* 2}$ \\ 1 , *2 School of Foreign Languages, Northwestern Polytechnical University, China
}

DOI: https://doi.org/10.29121/granthaalayah.v5.i4.2017.1801

\begin{abstract}
Metadiscourse refers to the method in organizing discourse, expressing the writer's attitudes towards the texts and readers. It has been studied by many scholars in discourse analysis in recent years. This article reviewed previous studies on metadiscourse, including definitions, classifications, theoretical studies and empirical studies. Moreover, critical comments on previous studies of metadiscourse were discussed. The analysis suggests that more studies are supposed to focus on different discourse genres and interdisciplinary research could also be explored in future studies.
\end{abstract}

Keywords: Metadiscourse; Theoretical Study; Empirical Study.

Cite This Article: Lichan Wang, and Yi Zhang (2017). "AN ANALYSIS OF THEORETICAL AND EMPIRICAL STIDIES ON METADISCOURSE." International Journal of Research Granthaalayah, 5(4), 118-127. https://doi.org/10.29121/granthaalayah.v5.i4.2017.1801.

\section{Introduction}

In general, people's communication consists of basic propositions and some other words which are used to organize texts and express speakers or writers' attitudes towards the text or audience (Wang \& Cheng, 2016). People always want to make their expressions been understood by others. Therefore, they will not simply list information promiscuously without organizing, but seek for some ways to have a better and clearer communication. Metadiscourse provides a way for people to express themselves and also involve readers in the communication. The concept of metadiscourse was first put forward by Zellig Harris in 1959 (Hyland, 2008). However, he did not give a clear definition, but regarded metadiscourse as "a way of understanding language in use" (Hyland, 2000). Ever since, many other scholars began to pay attention to the term metadiscourse and developed its concept. Some scholars used different terms to name it. For example, Meyer came up with a concept of "signaling" and Schiffrin named the concept of metadiscourse as "metatalk" (Wang \& Cheng, 2016). 
Since 1980s, metadiscourse has become the focus of applied linguistics (Wang \& Cheng, 2016). A number of researches have been done to analyze the use of metadiscourse in written or spoken discourse. This article reviewed the definition and classification of metadiscourse. What's more, previous theoretical and empirical studies on metadiscourse were also discussed.

\section{Definition of Metadiscourse}

\subsection{Definitions of Metadiscourse from Non-Propositional Aspect}

The definition of metadiscourse was not very clear when it was put forward at first. It was often simply regarded as "discourse about discourse" (Hyland, 2008). In many scholars' opinions, metadiscourse is different from the propositional component in that it does not convey the exact meaning of texts. Therefore, those scholar's definitions are non-propositional based. Lautamatti (1978) considered metadiscourse as "non-topical linguistic material". According to his study, metadiscourse was not related to the content of texts, but it did play an important role in understanding the whole discourse.

Similarly, Crismore and Vande Kopple also believed that metadiscourse was distinct from the propositional information. Crismore (1983) regarded metadiscourse as "the authors instruction into the discourse, either explicitly or non-explicitly, to direct rather than inform, showing readers how to understand what is said and meant in the primary discourse and how to 'take' the author". Vande Kopple (1985) defined metadiscourse as "the linguistic material which does not add propositional information but which signals the presence of an author". However, metadiscourse is not an independent element which can be included or not without changing the discourse meaning. We cannot distinguish the discourse by primary level (propositions) and secondary level (metadiscourse). In addition, texts are not simply the list of propositions. The meaning of one discourse depends on the two aspects together, namely propositional aspects and metadiscoursal aspect.

\subsection{Definition from Interpersonal Aspect}

As discourse conveys the author's idea to one thing or phenomenon, it cannot be neutral. Therefore, metadiscourse is not only text-referential, but also interpersonal. What cannot be neglected in the metadiscourse analysis is its interpersonal function. Metadiscourse shows writers' estimate to readers' recognition to the discourse and their needs in understanding discourse. Texts are organized together according to the strategy of reader-oriented for better communication, thus metadiscourse is also reader-oriented and interpersonal. Hyland (2000) defined metadiscourse as "the linguistic resources used to organize a discourse or the writer's stance towards either its content or the reader". He also gave a useful and clear definition, which stated, "Metadiscourse is the cover term for the self-expressions used to negotiate interactional meanings in a text, assisting the writer or speaker to express a viewpoint and engage with readers as members of a particular community". Hyland not only stressed the text organization function of metadiscourse, but also sated its interpersonal function, such as evaluation and engagement (Hyland, 2008). Therefore, his definition is used more frequently in discourse analysis in recent years. 


\section{Classifications of Metadiscourse}

Vande Kopple (1985) first put forward a comprehensive classification of metadiscourse based on Williams' classification. He classified metadiscourse into two broad categories: textual metadiscourse and interpersonal metadiscourse. Both of the two categories included several subcategories. However, there exists ambiguity in Vande Kopple's classification, which makes it difficult to be applied in practice well. For example, in academic papers, "according to X" can usually be seen as narrators or validity markers. This makes his classification vague, to some extent.

Crismore (1983) reorganized Vande Kopple's classification. He classified textual metadiscourse into textual markers and interpretive markers. Besides, several subcategories were also reorganized. Crismore improved Vande Kopple's classification. For example, reminders refer to the earlier parts of texts and announcements refer to the later parts of texts. However, the reminders belong to textual markers, but the announcements belong to interpretive markers. Therefore, Crismore's classification is not perfect as well.

Hyland (2000) classified metadiscourse into interactive metadiscourse and interactional metadiscourse. Interactive metadiscourse shows the writer's awareness of readers in organizing discourse. It can help writers to express their arguments and guide readers' interpretations as the writer assumed. Interactional metadiscourse focuses on the interaction with readers. It aims to involve readers in the argument and help the writer to express his or her attitude towards the text and readers. The details about Hyland's classification are shown in table 1.

Table 1: Hyland's model of metadiscourse

\begin{tabular}{|c|c|c|}
\hline Category & Function & Examples \\
\hline Interactive & $\begin{array}{l}\text { Help to guide the reader through } \\
\text { the text }\end{array}$ & \\
\hline Transitions & $\begin{array}{l}\text { Express relations between main } \\
\text { clauses }\end{array}$ & in addition; but; thus; and \\
\hline Frame markers & $\begin{array}{l}\text { Refer to discourse acts. } \\
\text { Sequences, or stages }\end{array}$ & $\begin{array}{l}\text { finally; to conclude; my } \\
\text { purpose is }\end{array}$ \\
\hline $\begin{array}{l}\text { Endophoric } \\
\text { markers }\end{array}$ & $\begin{array}{l}\text { Refer to information in other } \\
\text { parts of the text }\end{array}$ & $\begin{array}{l}\text { noted above; see Fig; in } \\
\text { section } 2\end{array}$ \\
\hline Evidentials & $\begin{array}{l}\text { Refer to information from other } \\
\text { texts }\end{array}$ & according to $\mathrm{X} ; \mathrm{Z}$ states \\
\hline Code glosses & $\begin{array}{l}\text { Elaborate } \\
\text { meanings }\end{array}$ & $\begin{array}{l}\text { namely; e.g.; such as; in other } \\
\text { words }\end{array}$ \\
\hline Interactional & Involve the reader in the text & \\
\hline Hedges & $\begin{array}{l}\text { Withhold commitment and open } \\
\text { dialogue }\end{array}$ & might; perhaps; possible; about \\
\hline Boosters & $\begin{array}{l}\text { Emphasize certainty or close } \\
\text { dialogue }\end{array}$ & $\begin{array}{l}\text { in fact; definitely; it is clear } \\
\text { that }\end{array}$ \\
\hline Attitude markers & $\begin{array}{l}\text { Express writer's attitude to } \\
\text { proposition }\end{array}$ & $\begin{array}{l}\text { unfortunately; I agree; } \\
\text { surprisingly }\end{array}$ \\
\hline
\end{tabular}




\begin{tabular}{lll}
\hline $\begin{array}{l}\text { Self mentions } \\
\begin{array}{l}\text { Engagement } \\
\text { markers }\end{array}\end{array}$ & $\begin{array}{l}\text { Explicit reference to author (s) } \\
\text { Explicitly build relationship with } \\
\text { reader }\end{array}$ & \begin{tabular}{l} 
consider; note; you can see that \\
\hline
\end{tabular}
\end{tabular}

(Adopted from Hyland, 2008)

\section{Theoretical Studies on Metadiscourse}

\subsection{Studies on the Concepts and Definitions of Metadiscourse}

Since Harris put forward the concept of metadiscourse, many scholars have studied the definition and concept of metadiscourse. Meanwhile, these scholars also provided different definitions of metadiscourse which has been shown in the previous section. After Harris, Meyer (1975) came up with a concept which was similar to metadiscourse, "signaling". He regarded signaling as a non-content system which organized the discourse and conveyed discourse information. Lautamatti (1978) believed metadiscourse was a non-topic material which can help readers in discourse understanding. Keller (1979) came up with "gambits" from the psycholinguistic aspect. He pointed out that speakers used gambits to lead to the topic and show speakers' attitudes towards the topic. Schiffrin (1980) treated metadiscourse as a linguistic form which organized and evaluated the conversation from the sociolinguistic aspect and he named it "metatalk".

In China, some scholars also studied the concept and translations of metadiscourse. Cheng (1997) first put forward the concept of metadiscourse. He translated metadiscourse into "Ya Yanyu". Li (2001) discussed the role of metadiscourse in context and explained the concept of metadiscourse further. Afterwards, Cheng and Jiang (2008) discussed three different translations of metadiscourse, "Ya Yanyu", "Yuan Huayu", "Yuan Yupian", and came up with a new translation: "functional discourse". However, this translation is not accepted by most scholars.

\subsection{Studies on the Functions of Metadiscourse}

When it comes to the function of metadiscourse, scholars hold different opinions. Most of them agree with the textual and interpersonal functions of metadiscourse. Keller (1979) analyzed 500 gambits and distinguished four main functions of gambits (metadiscourse): semantic framing, social signaling, state-of-consciousness signaling, and communicative signaling. Vande Kopple (1985) believed metadiscourse had the function in helping readers to organize, interpret and evaluate the discourse. Hyland (2008) stressed the integrity of metadiscourse on textual and interpersonal functions according to Halliday's three metafunctions of discourse. Yang (2007) explained metadiscourse and linguistic function in his research. He demonstrated that metadiscourse was influenced by Halliday's three metafunctions of discourse and he paid attention to the interactivity among ideational meaning, interpersonal meaning and textual meaning.

\subsection{Studies on Metadiscourse and Other Linguistic Theories}

Studies on metadiscourse and other linguistic theories are fruitful these years. Beauvais (1989) used speech act theory to study metadiscourse from the social communication perspective. He 
argued metadiscourse was the linguistic element which was used to express illocutionary meanings. Xin and Huang (2010) explored the relationship between metadiscourse and evaluative resources. Their research findings suggested that metadiscourse did not have evaluative meaning, but it had connections with the evaluative resources. Shi and Wang (2014) analyzed the communicative action meaning of metadiscourse in academic writings from the perspective of communicative action theory. They argued that metadiscourse in academic writings could realize the four universal validity principles of effective communication.

Besides, some scholars also studied the function of metadiscourse on inter-subjectivity constructing from the perspective of linguistic philosophy (Cheng, 2009; Xin, 2011; Zhao, 2015). In the study of metadiscourse from the cognitive perspective, Zhao (2016) analyzed the inference and constraint of metadiscourse based on the relevance theory. His results showed that metadiscourse could constraint listeners in contextual inference.

\section{Empirical Studies on Metadiscourse}

\subsection{Studies on Spoken Language}

Researches on metadiscourse in spoken language focus mostly on the metadiscourse used in classroom teaching. Joseph and Nicholas (2015) analyzed the metadiscourse used by teachers in EAP lessons and academic lectures. They selected 18 EAP lessons and 18 university lectures from two corpora and compared the metadiscourse using in the 36 samples. The results showed that EAP teachers were concerned with the framing of discourse firstly in order to set up classroom tasks and involve students in the class. Nevertheless, university instructors primarily concentrated on establishing relationships among ideas in the arguments. In addition, the EFL teachers' use of metadiscourse in university classes was also analyzed by many scholars (Yan \& Zhang, 2013; Guo, 2014). They analyzed the classroom metadiscourse through multidimensional functional analysis and found that the interactional and meta-linguistic functions of classroom metadiscourse outperform the interactive metadiscourse.

Si (2014) analyzed spoken English teaching in college based on the metadiscourse theory. She selected 69 non-English major students as the experimental subjects and collected their oral performance and the transcripts of oral tests. Finally, she found out that metadiscourse training was helpful to students' metadiscourse awareness and oral proficiency. In addition, metadiscourse used in business negotiation was also analyzed in these years (Xie, 2012).

\subsection{Studies on Non-Academic Discourse}

There are many metadiscourse studies on different discourse types, such as news, political texts and business emails. María and Rut (2015) analyzed and compared metadiscourse features in business e-mails which were written by three groups of non-native speakers of English, Spanish and Chinese. What they mainly studied were those differences in the use of the subcategory of interactional metadiscourse: boosters. Results showed that Spanish writers preferred to greater assertiveness. 
As for news discourse, Huang and Gong (2014) compared the use of metadiscourse in English news reports and English news comments. They selected 30 news reports and news comments respectively, and compared the similarities and differences of metadiscourse features in the two types of news discourse. More analyses on metadiscourse features in news discourse were studied by other scholars from different perspectives (Liu, 2013; Davud \& Manijheh, 2014; Huang \& Xiong, 2012). Moreover, Lu (2012) comprehensively analyzed metadiscourse in political texts based on Report on the Work of Government (2012).

\subsection{Studies on Academic Discourse}

Since the concept of metadiscourse was put forward, many scholars used it to analyze academic discourse and discussed its functions in academic writing. Hyland (2004) analyzed 240 masters' and doctors' theses from 6 different disciplines. He found that masters and doctors from different disciplines preferred to use metadiscourse differently in an unconscious way. His results also suggested how writers used metadiscourse to organize their texts and offer their work in academic writing. He believed that metadiscourse was an important method in analyzing academic writing.

Gillaerts and Van de Velde (2010) carried out a diachronic study on the interactive metadiscourse. They collected 72 abstracts which belong to the Journal of Pragmatics from 1982 to 2007. It was confirmed that the use of interactive metadiscourse changed in the past 25 years. Except for the abstracts, introductions were also analyzed. Tomoyuki (2015) compared metadiscourse features in the introductions of doctors' theses and research articles. Results showed that metadiscourse were used more frequently in introductions of research articles. Moreover, Zhou (2014) compared metadiscourse features in art and science research articles. He demonstrated that the frequencies of interactive and interactional metadiscourse were both higher in art research articles than they were in science research articles.

\subsection{Studies on the Comparison of Metadiscourse Among Different Languages}

Studies on the comparison of metadiscourse among different languages mainly focused on the comparison of English and other languages, such as Chinese, Spanish and so on. Valero-Garces (1996) analyzed the use of metadiscourse in English economic theses by American and Spanish. He found that the former used more metadiscourse than the later. Similarly, Joseph and Elliott (2014) also compared the use of metadiscourse in masters' theses by English and Spanish. The corpus they used consisted of 200 results and discussions parts of masters' theses. In these 200 samples, 100 samples were written by L1 Spanish students and the other 100 samples were written by English students. The comparative results revealed significant differences in using metadiscourse between the two different languages.

Comparison of metadiscourse between Chinese and English papers can also be searched. Hu and Cao (2011) compared hedges and boosters used in the abstracts of English and Chinese applied linguistic articles based on a corpora of 649 abstracts. Their results revealed that abstracts of English articles used more hedges than abstracts of Chinese articles did. Moreover, this research also showed that the different patterns of hedges and boosters in Chinese and English abstracts had influences on the expression of authorial certainty and confidence. 


\subsection{Studies on the Translation of Metadiscourse}

Except for the discourse analysis, more and more scholars focus on the translation of metadiscourse in different discourse. Wu (2014) observed the translator's subjectivity in metadiscourse translation. He believed that translators were more autonomous in metadiscourse translation compared with other linguistic components translation. Meanwhile, in metadiscourse translation, translators are supposed to have profound background knowledge. Therefore, translators' subjectivity was supposed to be concerned in metadiscourse translation. Some scholars also analyzed one specific translation version to study the metadiscourse translation. Ju (2015) observed the interpersonal metadiscourse used in English version of The Analects. The study showed that interpersonal metadiscourse was a powerful method in constructing rhetorical ethos. Furthermore, some scholars also observed the translation of one or several single metadiscourses such as "you" in Chinese from the micro perspective, which enriched the study of metadiscourse from different perspectives and also provided some references for the teaching of translation (Huang \& Wang, 2010).

\section{Critics on Previous Studies}

\subsection{Features of the Previous Metadiscourse Studies}

Different scholars hold different understanding on the definition, function and classification of metadiscourse. However, what accepted by most scholars is Hyland's metadiscourse theory. Therefore, it is Hyland's definition and classification of metadiscourse which are used more frequently in discourse analysis. The current literature shows that discussions on metadiscourse theory mainly focus on metadiscourse itself. However, some scholars also combined metadiscourse and other theories to investigate the use of metadiscourse, such as communicative action theory (Shi \& Wang, 2014), inter-subjectivity constructing (Cheng, 2009; Xin, 2011), relevance theory (Zhao, 2016).

As for the application of metadiscourse in discourse analysis, scholars analyzed many different types of discourse and also adopted different research methods in their studies. According to the current literature, the application of metadiscourse in discourse analysis includes the use of metadiscourse in speaking, writing and translation. As for the studies of metadiscourse in both written and oral texts, some scholars analyzed several single words (Huang \& Wang, 2010) and some analyzed the whole system of metadiscourse (Yan \& Zhang, 2013; Guo, 2014; Xie, 2012; $\mathrm{Si}, 2014)$. Moreover, the texts types in metadiscourse analysis are also various, including academic papers (Zhou, 2014), news discourse (Huang \& Xiong, 2012; Huang \& Gong, 2014), political texts (Lu, 2012), classroom discourse (Guo, 2014), but most studies mainly focus on metadiscourse in academic papers.

\subsection{Limitations of the Previous Metadiscourse Studies}

First, there is not a unified understanding of the definition, classification and function of metadiscourse, which makes it difficult to analyze the metadiscourse used in different discourses. More researches are supposed to be carried in this area. 
Second, regarding the research method, most previous studies use the self-built corpora to analyze a certain discourse type, and SPSS (Statistical Package for Social Sciences) is used to do the quantitative analysis. However, studies are mainly based on quantitative analysis with a small part on qualitative analysis.

Third, as for the research subjects, quite a lot of previous studies concentrated on the written discourse, while researches on metadiscourse in oral discourse and the translation of metadiscourse are still rare. On the study of metadiscourse in written discourse, most studies only focus on several common words. However, studies on the whole system of metadiscourse in academic papers from different disciplines are not profound.

Fourth, the discourse genre in previous analysis is limited. Most of previous studies focus on the research articles, thesis or news discourse. Studies on some discourse genres like literary works, political speeches. Legal discourse and text books are not profound.

\section{Conclusions}

In this article, the theoretical foundation and literature review of previous studies on metadiscourse are discussed. Meanwhile, comments on the previous studies on metadiscourse are offered. Metadiscourse has been widely used by many scholars in discourse analysis, and the application of metadiscourse is also various which consists of research articles, theses, news discourse and so on. It is recommended that more studies focus on the qualitative study of metadiscourse. Moreover, interdisciplinary research and different discourse genres can also be considered in the future studies.

\section{Acknowledgements}

This study is supported by Talent Plan for Social Science of Shaanxi Province (No.2016KA190001C190001) and the Seed Foundation of Innovation and Creation for Graduate Students in Northwestern Polytechnical University (No. Z2017062) . We are very grateful to graduate student Yishan Gao for her constructive suggestions to improve this article.

\section{References}

[1] Beauvais, P. A. (1989). Speech Act Theory of Metadiscourse. Written Communication 1: 11-30.

[2] Cheng Xiaoguang and Jiang Hui. (2008). Metadiscourse: Ya Yanyu, Yuan Huayu or Yuan Yupian? Foreign Language and Their Teaching 5:45-58.

[3] Cheng Xiaoguang. (1997). Researches on metadiscourse. Dalian: Liaoning Normal University Press.

[4] Cheng Xiaoguang. (2009). Construction of Subjectivity and Intersubjectivity from the Perspective of the Philosophy of Language. Foreign Language Research 1: 9-15.

[5] Crismore, A. (1983). Meta-discourse: What It Is and How It Is Used in Social Science Texts (Tech. Rep. No. 273). Urbana-Champaign: University of Illinois, Center for the Study of Reading.

[6] Davud Kuhia and Manijheh Mojood. (2014). Metadiscourse in Newspaper genre: a Cross Linguistic Study of English and Persian Editorials. Procedia-Social and Behavioral Sciences 3: 1046-1055. 
[7] Gillaerts, R. and Van de Velde, F. (2010). Interactional metadiscourse in research article abstracts. Journal of English for Academic purposes 2: 128-139.

[8] Guangwei Hu and Feng Cao. (2011). Hedging and boosting in abstracts of applied linguistics articles: A comparative study of English- and Chinese-medium journals. Journal of Pragmatics 4: 2795-2809.

[9] Guo Hongwei. (2014). A Three-dimensional Study on English Teachers' Metadiscourse in Chinese University Classroom Discourse. Foreign Languages in China 3: 60-67.

[10] Huang Qin and Gong Mengnan. (2014). A Comparative Study of the Use of Metadiscourse News Reporting and English News Commentary. Contemporary Foreign Languages Studies 5: 16-20.

[11] Huang Qin and Wang Xiaoli. (2010). A Corpus Based Comparative Analysis on Metadiscourse "You" in Hong Lou Meng and Its English Translation. Journal of Xi'an International Studies University 3:96-99.

[12] Huang Qin and Xiong Yao. (2012). A Comparative Analysis of the Use of Metadiscourse in English and Chinese News Commentaries. Foreign Language Research 1: 99-103.

[13] Hyland, K. (2000). Disciplinary Discourse:Social Interactions in Academic Writing. Pearson Education.

[14] Hyland, K. (2004). Disciplinary interactions: metadiscourse in L2 postgraduate writing. Journal of Second Language Writing 13: 133-151.

[15] Hyland, K. (2008). Metadiscourse. Foreign Language Teaching and Research Press.

[16] Joseph J. Lee and J. Elliott Casal. (2014). Metadiscourse in Results and discussion chapters: A cross linguistic analysis of English and Spanish thesis writers in engineering. System 7: 39-54.

[17] Joseph J. Lee. \& Nicholas C. Subtirelu. (2015). Metadiscourse in the classroom: A comparative analysis of EAP lessons and university lectures. English for Specific Purposes 6: 52-62.

[18] Ju Yumei. (2015). On International Metadiscourse in the English Translated Text of The Analects and Its Function in Constructing Rhetorical Ethos. Journal of Foreign Languages 6: 79-88.

[19] Keller, E. (1979). Gambits: Conversational strategy signals. Journal of Pragmatics 3: 219-228.

[20] Lautamatti, L. (1978). 'Observations on the development of the topic in simplified discourse'. In V. Kohonen and N.E. Enkvist (eds), Text Linguistics, Cognitive Learning, and Language Teaching. Turku: University of Turku Publications.

[21] Li Zuowen. (2001). Contextualizing Functions of Metadiscourse. Journal of Foreign Languages 3: 44-50.

[22] Liu Shufen. (2013). A Comparative Analysis of the Use of Metadiscourse in American and Chinese News Commentaries. Contemporary Rhetoric 2: 83-89.

[23] Lu Ying. (2012). On Interactional Metadiscourse in Political Texts. Foreign Language Research, 5: $52-55$.

[24] María Luisa Carrió-Pastora. and Rut Muñiz Calderónb. (2015). A contrastive analysis of metadiscourse features in business e-mails written by non-native speakers of English. ProcediaSocial and Behavioral Sciences 2: 214-221.

[25] Meyer, B. (1975). The Organization of Prose and Its Effects on Memory. Amsterdam: NorthHolland.

[26] Schiffrin, D. (1980). Metatalk: Organizational and evaluative brackets in discourse. Sociological Inquiry: Language and Social Interaction 50: 199-236.

[27] Shi Shunliang and Wand Sanwu. (2014). The Analysis of Communicative Action Meaning of Metadiscourse in English Academic Discourse. Shandong Foreign Language Teaching Journal 5:40-48.

[28] Si Bingyue. (2014). Analysis of Metadiscourse-Based College English Speaking Teaching. Foreign Language Research 1: 121-124.

[29] Tomoyuki Kawase. (2015). Metadiscourse in the introductions of $\mathrm{PhD}$ theses and research articles. Journal of English for Academic Purposes 8: 114-124. 
[30] Valero-Garces, C. (1996). Contrastive ESP rhetoric: metatext in Spanish-English economics texts. English for Specific Purposes 4: 279-294.

[31] Vande K. (1985). Some exploratory discourse on metadiscourse. College Composition and Communication 36: 82-93.

[32] Wang Qiang and Cheng Xiaoguang. (2016). A Review of the Theoretical Perspectives of Metadiscourse Research. Foreign Languages and Their Teaching 2: 55-62.

[33] Wu Xiaojun. (2014). On Translator's Subjectivity in Metadiscourse Translation. Foreign Language Research 6: 7-10.

[34] Xie Qun. (2012). Metadiscourse Analysis in Business Negotiation. Foreign Languages Research 4: $19-23$.

[35] Xin Zhiying, Huang Guowen. (2010). Evaluation-assigning Functions of Metadiscourse. Foreign Language Education 11: 1-5.

[36] Xin Zhiying. (2011). Intersubjectivity-constructing Resources in Academic Texts: Identification, Assessment and Application. Journal of University of Science and Technology Beijing (Social Science Edition) 6: 23-28.

[37] Yan Tao and Zhang Liyun. (2013). A Corpus-based Multi-dimensional Functional Analysis of the Mechanism of EFL Teachers' Classroom Metadiscourse. Journal of PLA University of Foreign Languages 3: 59-64.

[38] Yang Xinzhang. (2007). Metadiscourse and Functional Linguistics. Foreign Languages and Their Teaching 12: 1-3.

[39] Zhao Gang. (2016). An Analysis of the Inference and Constraint of Metalanguage Based on Relevance Theory. Japanese Study and Research 1: 1-8.

[40] Zhou Qijun. (2014). A Contrast Study of Metadiscourse in Abstract. Foreign Language Research 3: 114-117.

*Corresponding author.

E-mail address: yizhang@nwpu.edu.cn 